\section{Bojko T., Abramova A. Skladannyy D., Vavulin P.}

\title{
SOFTWARE IMPLEMENTATION OF THE TECHNOGENIC RISK A5SESSMENT METHOD OF AN INDUSTRIAL OBJECT USING THE MONTE-CARLO METHOD
}

Об'єктом дослідження є техногенний ризик промислового об'єкта. Одним із найбільш проблемних місць $\epsilon$ невизначеність вихідної інформації щодо об'єкту дослідження та відсутність універсальної методики, що дозволяла би проводити оцінювання техногенних ризиків на усіх стадіях функиіонування промислового об'єкта. Особливо така гостра проблема стосується потенційно-небезпечних виробництв.

Проведено аналіз існуючих методів та підходів до оцінювання техногенних ризиків промислових об'єктів на різних стадіях їх функиіонування. Встановлено, що одним із найкращих методів є метод Монте-Карло, який дозволяе кількісно оцінювати невизначеність рімень. Обгрунтовано використання методу МонтеКарло при проведенні кількісного аналізу небезпек з метою визначення ймовірності аварій та нещасних випадків, величини ризику, величини можливих наслідків.

В ході дослідження використано елементи теорії надійності для кількісного оцінювання ризиків. Кількісний аналіз небезпек у відповідності до теорії надійності дає змогу визначити ймовірність аварій та нещасних випадків, величину ризику, величину можливих наслідків. Методи розрахунку ймовірностей та статистичний аналіз є складовими частинами кількісного аналізу небезпек та техногенного ризику.

Розроблено алгоритм визначення техногенного ризику промислового об'єкта із використанням теорії надійності. Розроблено програмний комплекс на основі теорії надійності із поєднанням моделювання роботи системи методом Монте-Карло. Розроблений програмний комплекс дозволяє проаналізувати рівні техногенного ризику при використанні тих чи інших способів з'єднання елементів системи, а також оцінити зміни надійності системи при використанні інших складових елементів. Роботу програми представлено на прикладі системи, складовими елементами якої є підігрівачі ПВТ1-7 (Україна) в технологічній системі ТЕЦ (теплова електростаниія). Досліджувана система знаходиться на границі неприйнятного та умовно-прийнятного рівнів небезпеки, що дає підстави для необхідності вжиття заходів по збільшенню надійності системи шляхом збільшення кількості резервних елементів системи, або поліпшення їх якості.

Ключові слова: техногенний ризик, метод Монте-Карло, теорія надійності, програмний комплекс, надійність системи.

Received date: 02.02.2020

Accepted date: 03.03.2020

Published date: 30.04 .2020

\section{Introduction}

Today, there are a large number of risk assessment techniques. A variety of technological schemes, limited initial data, the difficulty of determining the consequences of accidents and their possible development scenarios affect the risk assessment procedure and lead to situations where the methods are used for other purposes. This subsequently leads to a negative impact on the adequacy of the risk assessment in the operation of potentially hazardous industries. Therefore, improving the mathematical and methodological apparatus for quantitative and qualitative risk analysis and creating a universal risk analysis algorithm is a promising and relevant issue in the world.

\section{The object of research and its technological audit}

The object of research is the technogenic risk of an industrial facility.
Copyright (C) 2020, Bojko T., Abramova A., Skladannyy D., Vavulin P. This is an open access article under the CC BY license (http://creativecommons.org/licenses/by/4.0)
One of the characteristic shortcomings inherent in the object of research is the uncertainty of the source information and the lack of a universal methodology that would allow an assessment of technological risks at all stages of the operation of an industrial facility. A particularly acute problem concerns potentially hazardous industries.

\section{The aim and objectives of research}

The aim of research is development of a software implementation of the methodology for assessing the technological risks of industrial facilities to facilitate decision-making on the operating conditions of the industrial facility and its condition. It is proposed to evaluate technogenic risk based on the theory of reliability with a combination of Monte Carlo simulation of system operation.

To achieve this aim, it is necessary to complete the following objectives:

1. To develop an algorithm for determining the technological risk of an industrial facility using the theory of reliability. 
2. To test the developed methodology for assessing technological risks using examples from the software package.

\section{Research of existing solutions of the problem}

Issues of assessment and analysis of technological risks today is one of the directions to increase the declaration of industrial safety in Ukraine and in the world as a whole. After analyzing the standards and the existing methodology for risk assessment [1,2], it is possible to conclude that they do not give an explicit idea of the procedure and methods for assessing technological risk.

The theory of risk analysis is created by many scientists who proposed a methodology for assessing hazard and risk, which is still widely used in world practice.

The direction of technogenic and environmental risk assessment is reflected in [3], but the proposed procedures and methods do not allow an assessment of technogenic risks in case of accidents.

Works $[4,5]$ are devoted to the development of an integrated method of risk assessment. In these works, a matrix model of risk assessment is proposed, but no attention is paid to calculating the level of risks during normal operation of the facility.

The authors of the studies [6, 7] believe that the issues associated with the interpretation of the concept of «risk» have some uncertainty that does not allow the development of a universal procedure for its assessment. The authors propose to consider risk as a probabilistic value and propose to compile event graphs when assessing the risk of accidents. But the question remains of numerically determining the magnitude of such a risk.

In [8], it is noted that the accident is a random variable, there is always a probability of its occurrence, therefore, one can't limit oneself to reducing the risk to an acceptable level. According to the concept of an acceptable level of risk, which replaced the concept of absolute safety, it is proposed to provide measures to localize the accident and eliminate its consequences. For this purpose, decision support systems in emergency situations are created in advance, allowing the decision maker through the implementation of optimal and most effective measures, with pre-calculated scenarios, to minimize the consequences of the accident.

In [9], it is proposed to conduct a risk assessment using the «scenario tree» method using the Monte Carlo method as the main method, which allows one to obtain more accurate results. The Monte Carlo method can be attributed to numerical methods that use the modeling of input (output) random variables, and their further mathematical transformation in accordance with the process under study, and the construction of output statistical estimates for the desired values. The experience of scientists shows that for such situations, it is possible to use the Monte Carlo method, which allows to use any methods of analysis of the source data with interval-probabilistic presentation.

The authors of [10] emphasize that thanks to the Monte Carlo method and based on the expected range of solutions, it is possible to more clearly formulate requirements for the accuracy with which the initial data should be presented.

Thus, the analysis results allow to conclude that the Monte Carlo method is the most acceptable for solving the tasks. This method allows to quantify the uncertainty of decisions, which obtain in conditions when information about some data is fuzzy.

\section{Methods of research}

The methodological basis for quantitative risk assessment is the theory of reliability. In accordance with this theory, a failure is considered as a random event, the causes of failures are set by the distribution function. A quantitative hazard analysis in accordance with the elements of the theory of reliability allows to determine the probability of accidents and accidents, the magnitude of the risk, the magnitude of the possible consequences. Probability methods and statistical analysis are integral parts of the quantitative analysis of hazards and technological risk.

Consider the reliability indicator of a technical object in terms of its reliability. Such an indicator is the probability of failure-free operation $P(t)$ - the probability that in a given interval $t=T$ there is no failure of this object. The value of this probability, like any other, lies in the interval $0 \leq P(t) \leq 1$ [1]. The probability of failurefree operation $P(t)$ and the probability of failure $F(t)$ form a complete group of events:

$$
P(t)+F(t)=1
$$

The permissible probability value $P(t)$ is selected depending on the degree of danger of failure.

The reason for the occurrence of sudden failures is not associated with a change in the state of the object and the time of its previous operation, but depends only on the level of external factors. Sudden failures are estimated by the failure rate $\lambda$ - the probability of failure per unit time, provided that by that time there were no failures [11]:

$$
\lambda=\frac{F\left(\frac{\Delta t}{t}\right)}{\Delta t}=\frac{1-p\left(\frac{\Delta t}{t}\right)}{\Delta t},
$$

where $\Delta t-$ the change in time; $t-$ the time, $\mathrm{s}$.

The main regularity of the theory of reliability:

$$
P(t)=e^{-\int_{0}^{t} \lambda \mathrm{d} t}=\exp \left[-\int_{0}^{t} \lambda(t) \cdot \mathrm{d} t\right] .
$$

When calculating the reliability of a complex system, structural schemes are used (Fig. 1).

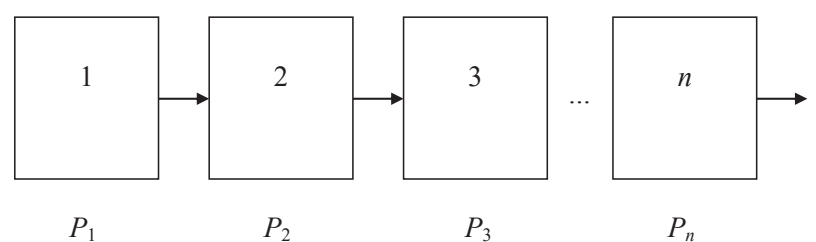

Fig. 1. The structural diagram of the reliable operation of the technical system

The probability of failure-free operation is equal to the product of the probability of failure-free operation of the elements of this system:

$$
P(t)=P_{1} \cdot P_{2} \cdot P_{3} \cdot \ldots \cdot P_{n}=\prod_{i=1}^{n} P_{i} .
$$


With a constant (loaded) backup, when the backup elements are constantly connected to the main ones and are in the same mode of operation with them, a system failure is a complex event that will occur when all elements fail.

The probability of the simultaneous appearance of all failures to have the form:

$$
F(t)=F_{1} \cdot F_{2} \cdot F_{3} \cdot \ldots \cdot F_{n}=\prod_{i=1}^{n} F_{i} .
$$

Therefore, the failure-free operation of the system:

$$
P(t)=1-\prod_{i=1}^{m} F_{i}=1-\prod_{i=1}^{n}\left(1-P_{i}\right) .
$$

A quantitative risk assessment by this method is an assessment of the numerical values of the probability and consequences of undesirable processes, phenomena, events, therefore, the reliability of such estimates should be treated with caution [11].

Usually, when assessing risk, it is characterized by two quantities - the probability of the event $P$ and the consequences $U$, which are factors in the expression of mathematical expectation:

$$
R=P X
$$

In relation to the sources of risk, its assessment involves the separation of the normal operating mode of $R_{H}$ and $R_{A B}$ emergency situations:

$$
R=R_{H}+R_{A B}=P_{H} X_{H}+P_{A B} X_{A B} .
$$

Technogenic risk is assessed according to a formula that includes both the probability of an undesirable event and the magnitude of the consequences in the form of damage $U$ :

$$
R=P U \text {. }
$$

If each event that occurs with probability $P_{i}$ corresponds to damage $U_{i}$, then the risk value will represent the expected value of damage $U$ :

$$
R=U_{*}=\sum_{i=1}^{n} P_{i} U_{i} .
$$

A logical analysis of the internal structure of the system and determining the probability of undesirable events $E$ as a function of individual events is one of the tasks of hazard analysis.

To automate the hazard assessment of industrial risks of industrial facilities during normal operation, the following mathematical models of the failure of a system of several elements were used.

By $P\left\{E_{i}\right\}$ let's denote the probability of an undesirable event $E_{i}$.

For a full group of events:

$$
\sum_{i=1}^{n} P\left\{E_{i}\right\}=1 \text {. }
$$

For exactly probable events $\left(P\left\{\Sigma E_{i}\right\}=p, i=1,2, \ldots, n\right)$ that form a complete group of events, the probability is $p=1 / n$.

Opposite events $E_{i}$ and $\left(-E_{i}\right)$ form a complete group of events, therefore:

$$
P\{E\}=1-P\{-E\}
$$

In practice, the objective probability formula is used:

$$
P\{E\}=\frac{n_{E}}{n},
$$

where $n$ and $n_{E}$ - the total number of cases and the number of cases in which an undesired event $E$.

The probability of an $E_{1}$ event under condition $E_{2}$ is denoted by $P\left\{E_{1} \mid E_{2}\right\}$.

If events $E_{1}$ and $E_{2}$ are non-adjacent, then let's obtain:

$$
P\left\{E_{1} E_{2}\right\}=P\left\{E_{1}\right\} P\left\{E_{2}\right\} .
$$

For $n$ independent events $E, E_{1}, \ldots, E_{n}$ let's obtain:

$$
P\left\{\prod_{i=1, n} E_{i}\right\}=\prod_{i=1}^{n} P\left\{E_{1}\right\}
$$

For system components and the system as a whole:

$$
\begin{aligned}
& p_{i}=P\left\{E_{i}\right\}, q_{i}=P\left\{-E_{i}=1-p_{i}\right\}, \\
& p=P\{E\}, q=P\{-E\}=1-p .
\end{aligned}
$$

The logical function of the system has the form:

$$
E=F\left(E_{1}, E_{2}, \ldots, E_{n}\right)
$$

Applying the rules of probability theory, let's find the probability of an undesirable event in the form of a threat function:

$$
p=F_{p}\left(p_{1}, p_{2}, \ldots, p_{n}\right) .
$$

An undesirable event in a technical system in which elements are connected in series can result in the failure of any component. If $E_{j}$ is the failure of the $j$-th component, then the failure of such a system is expressed by the following equation [11]:

$$
E=E_{1}+E_{2}+\ldots+E_{n}=\sum_{j=1, m} E_{j},
$$

where $m$ - the number of components (elements) of the system.

If the failures of the elements are independent, then the probability of failure in such a system is expressed as follows:

$$
P\left\{\sum_{j=1} E_{j}\right\}=1-P\left\{\sum_{j=1, m} E_{j}\right\}=1-\prod_{j=1}^{m}\left(1-P\left\{E_{j}\right\}\right) .
$$

For exactly probable failures, the probability of failure in such a system:

$$
P\{E\}=1-(1-p)^{m} .
$$

This shows that in the case of complex systems there is a rather high probability of failure. Let's consider systems whose elements are connected in parallel.

The failure of such a system leads only to the failure of all its elements:

$$
E=E_{1} \cdot E_{2} \cdot \ldots \cdot E_{m}=\prod_{j=1, m} E_{j}
$$

If the failures of the elements can be considered interdependent, then the probability of failure in such a system will be as follows: 


$$
P\{E\}=\prod_{j=1}^{m} P\left\{E_{j}\right\}
$$

In practice, the use of such systems is a backup operation, which is used when it is necessary to achieve a high degree of reliability.

Risk level assessment is carried out according to the classification given in [12].

It is proposed to use the Monte Carlo method to conduct a quantitative hazard analysis in order to determine the probability of accidents and accidents, the magnitude of the risk, and the magnitude of the possible consequences. The Monte Carlo method is used to simulate processes that are affected by random factors, and also makes it possible to analyze and evaluate various «scenarios» of implementation of decisions and take into account various risk factors in one approach. It is based on obtaining pseudo-random numbers; when solving problems, they are used as random [11]. An important advantage of this method is its simplicity, the essence of which is as follows: to build a model, it is necessary to write down one cycle of the model implementation, and then repeat it a certain number of times, depending on the accuracy of the calculated characteristic.

When using the Monte Carlo method, the probability of failure of an element of a system or system is determined by the following relationship:

$$
P=\frac{N^{*}}{N}
$$

where $N^{*}$ - the number of failures of an element of a system or system during the simulation; $N$ - the total number of iterations (repetitions) of the algorithm in which the system was modeled.

This method allows to reduce most of the calculations in a simple relationship (24), which greatly simplifies the determination of the probability of equipment failure.

\section{Research results}

6.1. Algorithm for determining technogenic risk and its software implementation. As a result of research and development of various theoretical and practical materials, an algorithm is developed to determine the technogenic risk of chemical industry objects and objects of other types of production (Fig. 2).
In order to facilitate decision-making on the operating conditions of an industrial facility and its condition by assessing technogenic risk, the RISK 1.2 software package [13] has been developed based on the theory of reliability with a combination of Monte Carlo simulation of system operation. The developed software package includes database elements that allow to analyze the level of technological risk when using various methods of connecting elements of the system, as well as when using various constituent elements. And also to evaluate changes in the reliability of the system when using other components.

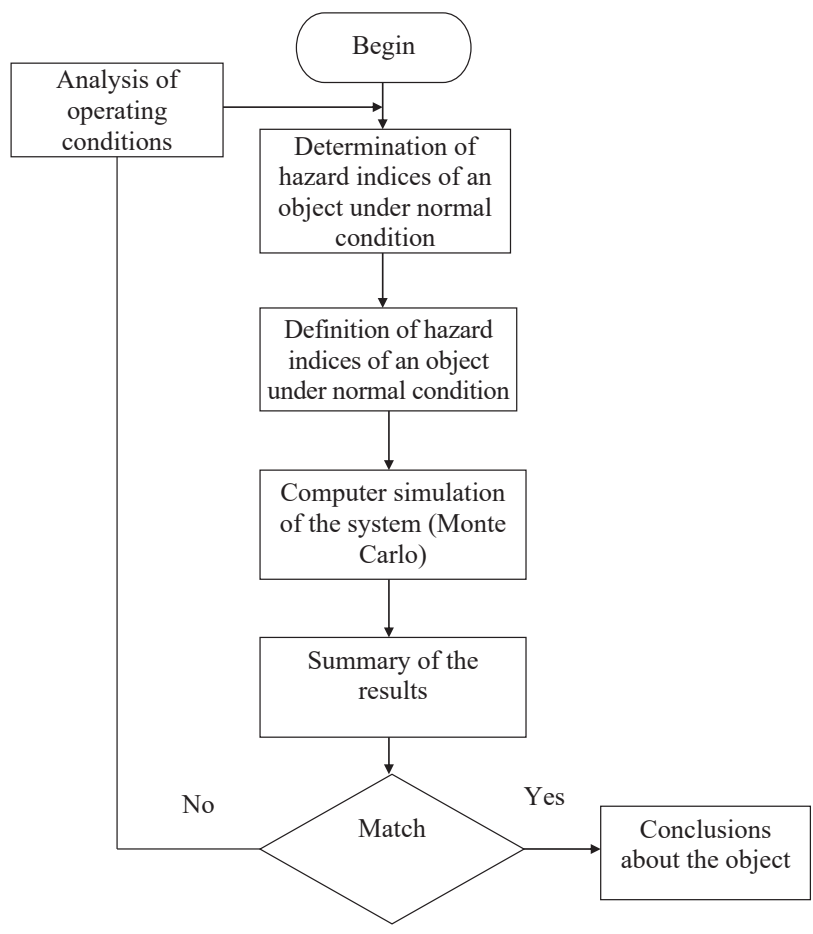

Fig. 2. The generalized algorithm for determining the technological risk of an industrial facility during operation

It is advisable to present the work of the program as an example of a system whose components are the heaters PVT1-7 (Ukraine) in the technological system of a thermal power plant (thermal power plant) [14].

After let's carry out the calculation (Fig. 3).

The results are presented in Fig. 4.

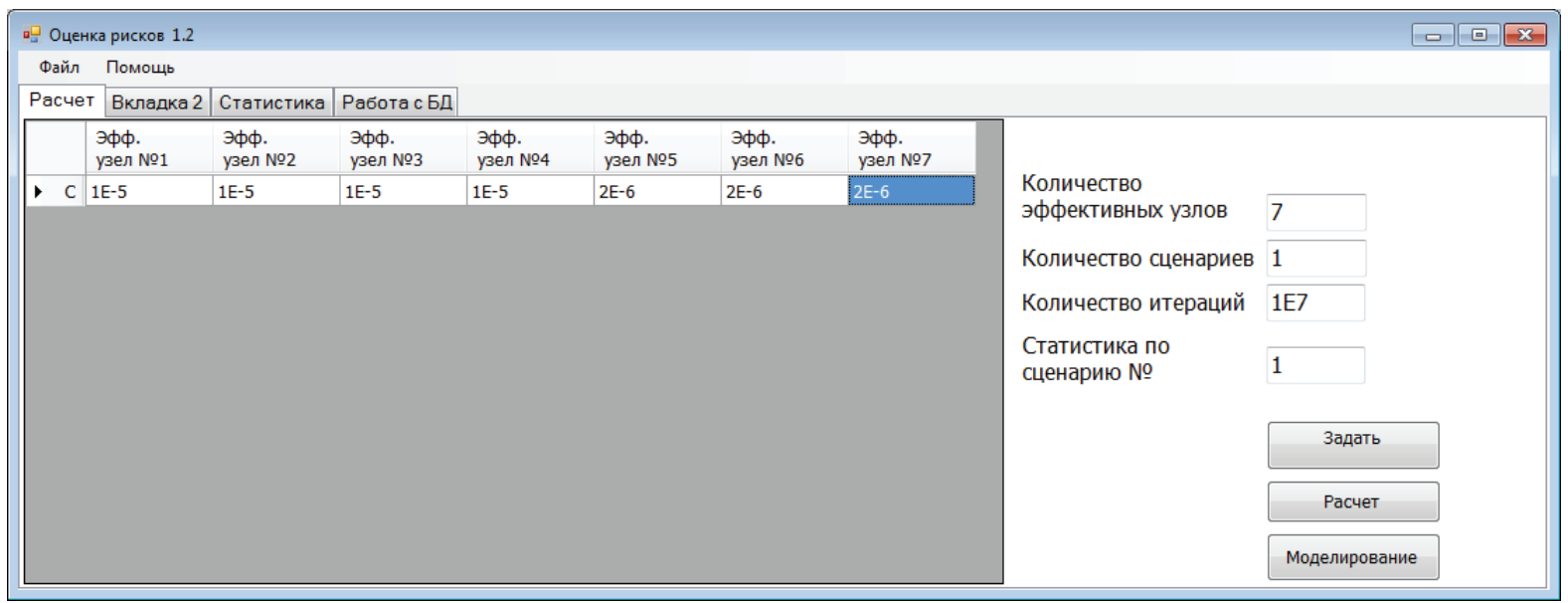

Fig. 3. Input window 


\begin{tabular}{|c|c|c|c|c|c|c|c|c|c|}
\hline \multicolumn{10}{|c|}{$\square$ Оценка рисков 1.2} \\
\hline \multirow{2}{*}{$\begin{array}{c}\text { Файл } \\
\text { Расчет }\end{array}$} & \multicolumn{3}{|l|}{ Помощь } & & & & & & \\
\hline & Вкладка 2 & Статистика & РаботасБД & & & & & & \\
\hline
\end{tabular}

Fig. 4. Calculation of the probability of system failure

Let's clarify the probabilities of failure of the system and its elements using the methods of mathematical modeling, namely, the Monte Carlo method (Fig. 5).

\begin{tabular}{|c|c|c|c|c|}
\hline \multicolumn{4}{|c|}{ Оценка рисков 1.2} & \multirow[t]{2}{*}{0 回 } \\
\hline Файл & Помощь & & & \\
\hline \multirow[t]{2}{*}{ Расчет } & Вкладка 2 & Статистика Рабо & тасБД & \\
\hline & & $\begin{array}{l}\text { Количество } \\
\text { итераций }\end{array}$ & $\begin{array}{l}\text { Количество } \\
\text { отказов }\end{array}$ & $\begin{array}{l}\text { Количество } \\
\text { простоев }\end{array}$ \\
\hline \multirow{7}{*}{ 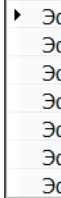 } & Ф. үзел №1 & 10000000 & 100 & 0 \\
\hline & Ф. узел №2 & 10000000 & 109 & 100 \\
\hline & Ф. үзел №3 & 10000000 & 98 & 209 \\
\hline & Ф. үзел №4 & 10000000 & 100 & 307 \\
\hline & Ф. узел №5 & 10000000 & 15 & 407 \\
\hline & Ф. узел №6 & 10000000 & 21 & 422 \\
\hline & Ф. үзел №7 & 10000000 & 27 & 443 \\
\hline
\end{tabular}

Fig. 5. The results of modeling the operation of the elements of a complex technological system

The probability of system failure is calculated equal to $P_{\text {failure }}=4.6 \cdot 10^{-5}$. The probability of failure of all elements of the system of $P_{\text {total failure }}=8 \cdot 10^{-38}$.

As can be seen from Fig. 3-5, to calculate the risks of technological equipment failure using the developed software package is quite simple. It should be noted that the possibility of using methods of the theory of reliability and computer modeling methods is a great advantage, because in addition to performing calculations using one method or another, it is always possible to verify the results.

6.2. Testing the developed methodology for assessing the technological risk of a system of water heaters of a thermal power plant. When assessing the possible risks of complex production, a mathematical method is used, which includes constructing a graph that characterizes the relationship between situations and risk factors. Based on this method, a scenario for the development of undesirable situations in a system consisting of seven water heaters was included in the technological system of a thermal power plant [14]. In particular, a scenario is considered in which the possibility of failure of one of seven parallel-connected water heaters is considered. From the point of view of the theory of reliability, they are considered as a system of seriesconnected elements, since a failure of one water heater leads to the inability to heat water in the required quantity, which results in a failure of the system as a whole.

The graph describing the heater system shown in Fig. 6 has such a structure, since it most accurately describes the nature of the interaction of its elements.

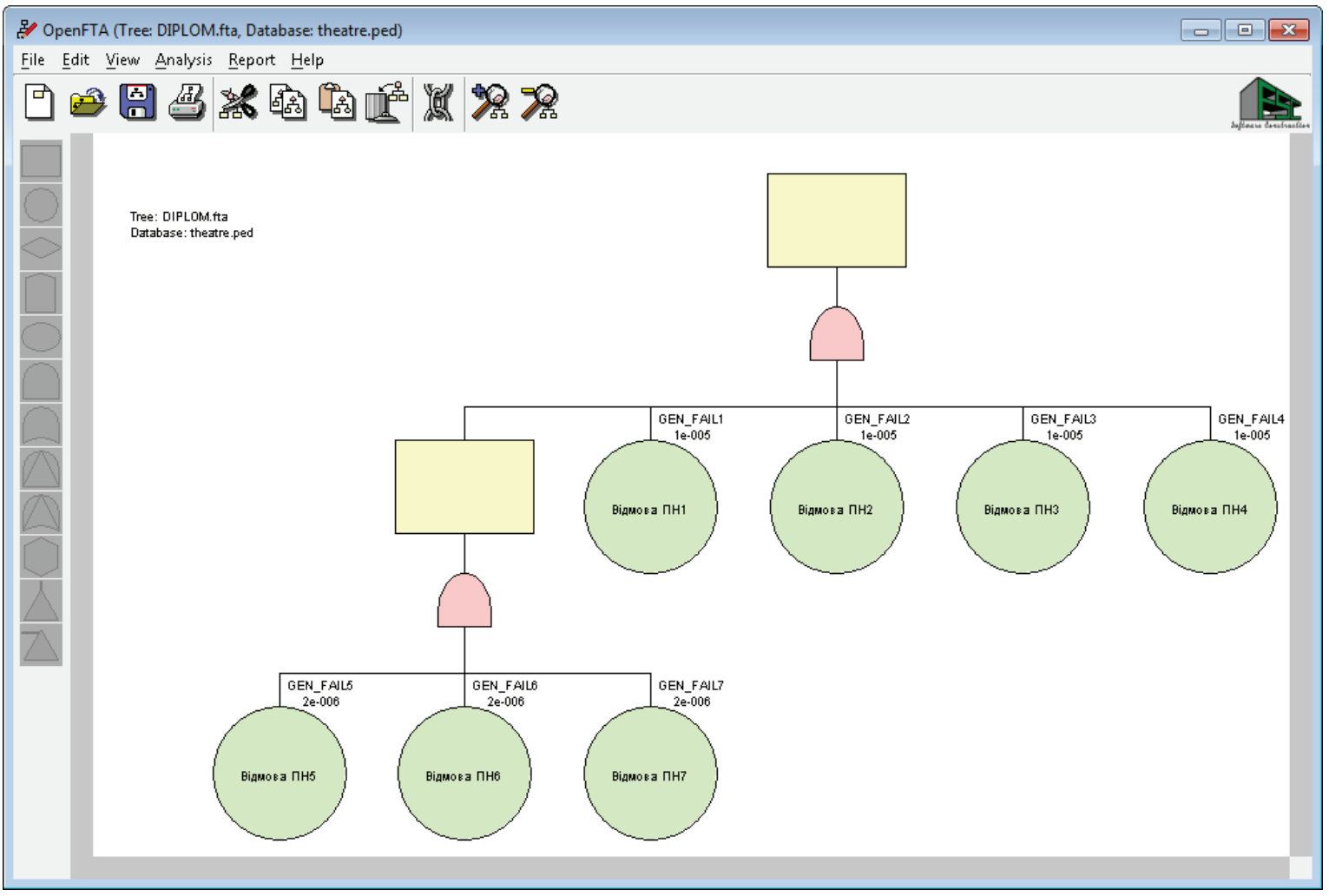

Fig. 6. Failure tree for a system of seven water heaters of a thermal power plant built in an OpenFTA environment 
When constructing the graph in the OpenFTA system, it is decided to divide the system elements into two branches: 3 functional elements in the first and 4 in the second. This section takes into account the differences between the heaters (the system uses 4 low pressure and 3 high heaters).

When implementing the developed algorithm, the following assumptions are made:

1) nominal probability of failure of the elements of the system are obtained on the basis of index estimates calculated earlier;

2) graph of the links between the situation, which can lead to equipment failure and risk factors, is presented in the form of a scenario.

Simulation methods are used to clarify the probability of failure of elements of a complex system and to calculate the technological risk of the system as a whole. More details in [14-16].

The system under consideration consists of 4 types of water heaters, which differ in their technical characteristics: hydraulic resistance, heating surface (from $350 \mathrm{~m}^{2}$ to $700 \mathrm{~m}^{2}$ ), maximum steam temperature (from $341{ }^{\circ} \mathrm{C}$ to $449{ }^{\circ} \mathrm{C}$ ), weight (from $10.4 \mathrm{t}$ to $635 \mathrm{t}$ ). The initial data necessary for the calculations are presented in Table 1.

Table 1

Baseline data for the quantification of technological risk

\begin{tabular}{|c|c|c|}
\hline Heater & Type & Rated probability of failure \\
\hline Low pressure heater No. 1 & PN-350-16-7-III & $1 \cdot 10^{-5}$ \\
\hline Low pressure heater No. 2 & PN-350-16-7-III & $1 \cdot 10^{-5}$ \\
\hline Low pressure heater No. 3 & PN-350-16-7-III & $1 \cdot 10^{-5}$ \\
\hline Low pressure heater No. 4 & PN-350-16-7-III & $1 \cdot 10^{-5}$ \\
\hline High pressure heater №. 1 & PV-700-265-13 & $2 \cdot 10^{-6}$ \\
\hline High pressure heater No. 2 & PV-700-265-31 & $2 \cdot 10^{-6}$ \\
\hline High pressure heater No. 3 & PV-700-265-45 & $2 \cdot 10^{-6}$ \\
\hline
\end{tabular}

The results are compared using index estimates [17] and the method proposed by the authors using the Monte Carlo method for a system of seven efficient units (water heaters) in the technological system of a thermal power plant. The first scenario uses, as initial data, the equipment failure probabilities calculated earlier by the index method [17]. The second scenario uses the probability values obtained for each heater by the Monte Carlo method and are, respectively, for heaters $1 \cdot 10^{-5}, 1.09 \cdot 10^{-5}, 0.98 \cdot 10^{-5}$, $1 \cdot 10^{-5}, 1.5 \cdot 10^{-6}, 2.1 \cdot 10^{-6}, 2.7 \cdot 10^{-6}$.

At the first stage, the probability of failures of one, two, three, etc., and all heaters is calculated at the same time. The probability of failure of the entire system is also calculated (the failure of at least one of the working elements leads to it). The probability of failure of the system as a whole includes the probability that several heaters in any combination of them will fail simultaneously (the first and second, fifth and sixth, or all at the same time). Using the simulation method, a series of tests was carried out with $10^{8}$ iterations to obtain the probability of equipment failure in normal operation. Let's present the obtained calculation results by different methods and compare them in the form of bar charts in Fig. 7. The error is $2 \%$.
The system is located on the border of an unacceptable and conditionally acceptable level of danger, which gives grounds for the need to take measures to increase the reliability of the system:

- or by increasing the number of backup system elements;

- or by improving their quality (installing more reliable heaters).

\section{SWOT analysis of research results}

Strengths. Compared with existing methods for assessing the industrial safety of industrial enterprises, an algorithm has been developed that allows the prediction of industrial risk in normal operation using the index approach and simulation method. This allows to take into account the actual performance of the enterprise and, accordingly, to obtain the value of technological risk for the actual conditions of operation, and therefore it is reasonable to manage the production process.

Weaknesses. Weaknesses include requirements for restrictions on the complexity of the structural diagrams of objects and, accordingly, the ability to apply division into functional blocks for large enterprises.

Opportunities. The level of technological risk directly depends on human activities. The introduction of new technologies entails an increase not only in the quality of life, but also in the level of possible technological hazards. Since there is a huge number of operating technological industries in the world, the assessment of technogenic risks over time becomes a very important aspect of the work of these enterprises, precisely because such an assessment can give correct results in predicting technological emergencies.

Threats. To use the developed software package, it is enough to have skills in working with computer programs, and to prepare the initial data and analyze the results obtained, it is necessary to know the basics of the theory of technological risks and reliability.

\section{Conclusions}

1. An algorithm for determining the industrial risk of an industrial facility based on the theory of reliability has been developed. This algorithm simplifies the decision- 
making procedure for the investigated object. A feature of the proposed algorithm is the prediction of anthropogenic risk under normal operation of the facility using the simulation method. Using this method allows to take into account the actual performance indicators and calculate the value of technological risk for the actual operating conditions, and therefore it is reasonable to control the production process.

2. The developed software package is tested using the example of a water heater system of a thermal power plant. The failure probability of the system and its elements is calculated using mathematical modeling methods, namely the Monte Carlo method. The probability of system failure is calculated equal to $P_{\text {failure }}=4.6 \cdot 10^{-5}$. The probability of failure of all elements of the system $P_{\text {total failure }}=8 \cdot 10^{-38}$. In order to verify the correctness of the results obtained, the results obtained using index estimates and the proposed Monte Carlo algorithm for a system of seven efficient nodes in the technological system of a thermal power plant are compared. The error is $2 \%$.

\section{References}

1. Metodyka vyznachennia ryzykiv ta yikh pryiniatnykh rivniv diia deklaruvannia bezpeky obiektiv pidoyshchenoi nebezpeky (2002). Ministerstvo pratsi ta sotsialnoi polityky Ukrainy No. 637. 04.12.2002. Available at: https://zakononline.com.ua/documents/ show/34982_ 34982

2. Normatyvy porohovykh mas nebezpechnykh rechovyn dlia identyfikatsii obiektiv pidoyshchenoi nebezpeky (2002). DNAOP 0.00-3.07-02. Kabinet Ministriv Ukrain No. 956. 11.07.2002. Available at: https://zakon.rada.gov.ua/laws/show/956-2002$\% \mathrm{D} 0 \% \mathrm{BF}$

3. Vorobev, Iu. L. (2000). Natsionalnaia bezopasnost i upravlenie strategicheskimi riskami v Rossii. Problemy bezopasnosti pri chrezoychainykh situatsiiakh, 5, 6-15

4. Kuhta, A. I. (2019). Integrated method of occupational risk degree assessment at the enterprise. Safety of technogenic and natural systems, 1, 18-27. doi: https://doi.org/10.23947/25419129-2019-1-18-27

5. Raj Pradeesh, T., Venkumar, P., Saravanamani, M. (2019). Hazard Identification using Risk Assesment for A Tyre Manufacturing Process. International Journal of Innovative Technology and Exploring Engineering, 9 (2S2), 353-356. doi: http://doi.org/ 10.35940/ijitee.b1054.1292s219

6. Fedosov, A. V., Badrtdinova, I. I., Abdrakhmanova, K. N., Velekzhanin, D. Y. (2019). Quantitative assessment of uncertainty of technogenic accidents risk analysis. Oil and Gas Business, 3, 46-66. doi: http://doi.org/10.17122/ogbus-2019-3-46-66

7. Quin, S., Widera, G. E. O. (1996). Uncertainty Analysis in Quantitative Risk Assessment.Journal of Pressure Vessel Technology, 118 (1), 121-124. doi: http://doi.org/10.1115/1.2842154
8. Grigorev, V. S. et. al. (1990). Nekotorye aspekty lokalizatsii i likvidatsii avariinykh vybrosov toksichnikh veshchestv. Vesnik vsesoiuznogo khimicheskogo obshchestvava im. D. I. Mendeleeva, 4 (35), 463-468.

9. Beati, J., Caira, M. (2004). Benchmarkon Dynamic Reliability An Approach based on Dynamic Event Tree Analysis. University of Rome «La Sapienza».

10. Smolich, S. V., Smolich, K. S. (2004). Reshenie gorno-geologicheskikh zadach metodom Monte-Karlo. Chita: ChiTGU, 103.

11. Alymov, V. T., Tarasova, N. P. (2006). Tekhnogennyi risk: Analiz $i$ otsenka. Moscow: Akademkniga, IKTS, 118.

12. Boiko, T. V., Vavulin, P. A. (2014). Calculation and analysis of predictable technological risk value of industrial objects in stationary operating conditions. Eastern-European Journal of Enterprise Technologies, 5 (10 (71)), 42-47. doi: http://doi.org/ 10.15587/1729-4061.2014.27981

13. Boiko, T. V., Abramova, A. O., Vavulin, P. A. (2018). A. s. No. 75863 UA. Programnii kompleks RISK 1.2. published: 12.01 .2018

14. Publichne aktsionerne tovarystvo «Kharkivska TETs-5». Available at: http://www.tec5.kharkov.ua/

15. Vavulin, P. A., Boiko, T. V. (2016). Analysis of algorithm for estimating distribution functions of random variables for the prediction of technogenic risk. Technology Audit and Production Reserves, 2 (3 (28)), 17-23. doi: http://doi.org/10.15587/23128372.2016.66754

16. Boiko, T. V., Baturynska, I. R. (2013). Definition man-caused risks based on the monte-carlo method. Eastern-European Journal of Enterprise Technologies, 2 (11 (62)), 4-7. Available at: http://journals.uran.ua/eejet/article/view/11721

17. Bendiuh, V. I. (2005). Systema otsinky tekhnohennoi bezpeky promyslovykh pidpryiemstv: metodolohiia ta alhorytm rozrakhunku. Kyiv, 193.

Bojko Tatyana, PhD, Associate Professor, Department of Cybernetics of Chemical Technology Processes, National Technical University of Ukraine «Igor Sikorsky Kyiv Polytechnic Institute», Kyiv, Ukraine, e-mail: tobojko@gmail.com, ORCID: http://orcid.org/ 0000-0002-9710-8055

Abramova Alla, PhD, Associate Professor, Department of Cybernetics of Chemical Technology Processes, National Technical University of Ukraine «Igor Sikorsky Kyiv Polytechnic Institute», Kyiv, Ukraine, e-mail: alla abramova@ukr.net, ORCID: http://orcid.org/ 0000-0003-3475-8584

Skladannyy Denys, PhD, Associate Professor, Department of Cybernetics of Chemical Technology Processes, National Technical University of Ukraine «Igor Sikorsky Kyiv Polytechnic Institute», Kyiv, Ukraine, e-mail: skl den@ukr.net, ORCID: http://orcid.org/00000003-3624-5336

Vavulin Petro, Consultant on Information and Telecommunication Technologies, Foreign Enterprise «I-AR-SI», Kyiv, Ukraine, e-mail: lestatxa81@gmail.com,ORCID: http://orcid.org/0000-0001-7299-2262 